\title{
Effect of Season on Growth Dynamics of Citrus aurantifolia cv. Kuliana Lime under Bhubaneswar Condition
}

\author{
Subhrajyoti Mishra ${ }^{1 *}$, Kommana Pavani ${ }^{1}$, Priyadarshini Dalei ${ }^{2}$ and Dilip Kumar Dash ${ }^{1}$ \\ ${ }^{1}$ Department of Fruit Science and Horticulture Technology, College of Agriculture, \\ OUAT, BBSR-03, India \\ ${ }^{2}$ Department of Entomology, College of Agriculture, OUAT, BBSR-03, India
}

*Corresponding author

\begin{tabular}{|c|c|}
\hline & T R A C T \\
\hline & \multirow{3}{*}{$\begin{array}{l}\text { An experiment was carried out to find the effect of different season on the growth } \\
\text { dynamics of Kuliana lime during } 2016-17 \text { at Horticultural Research Station, Department of } \\
\text { Fruit Science and Horticulture Technology, O.U.A.T., Bhubaneswar. Acid lime being } \\
\text { tropical fruit crop, its flushing is dependent on the variation of climatic factors. Generally, } \\
\text { the timing and rate of vegetative and reproductive growths are regulated by autonomous or } \\
\text { environmental factors. Before going for breeding work for crop improvement, one should } \\
\text { have sound knowledge on the growth pattern of the Kuliana lime plant. The vegetative } \\
\text { growth of the plant like plant height, girth, canopy volume, number of leaves per shoot, } \\
\text { number of spines per shoot, length of shoot, diameter of the shoot, internode length, dry } \\
\text { weight of the shoot are recorded to be highest during the rainy season and spring season } \\
\text { was best in production of new growth flush or tertiary shoots. The Canopy spread during } \\
\text { spring season and rainy season were at par with each other and minimum was recorded } \\
\text { during the winter season. }\end{array}$} \\
\hline Article Info & \\
\hline $\begin{array}{l}\text { Accepted: } \\
\text { 26 January } 2018 \\
\text { Available Online: } \\
\text { 10 February } 2018\end{array}$ & \\
\hline
\end{tabular}

\section{Introduction}

Citrus is a highly priced fruit crop having significant importance in the fruit economy of our country. It is the second fruit crop in India with respect to area and third largest with respect to production after mango and banana. Acid Lime (Citrus aurantifolia Swingle), from the family Rutaceae originated in India and then spread to the Middle East and other tropical and subtropical countries.

The major citrus producing countries are Brazil, Spain, USA, Israel, Morocco, China,
Mexico, Russia, India, Canada, South Africa etc. In India, it is cultivated in 1.042 Mha area with the production of $10.089 \mathrm{MT}$, among which lemon and lime contribute about 0.255 Mha in area, 2.523 MT on production basis and the major producing states are Maharastra, Andhra Pradesh, Punjab etc (NHB database 2014). Odisha accounts for $2.4 \%$ and ranked $9^{\text {th }}$ to the national production of citrus fruits. Mayurbhanj, Keonjhar, Koraput, Ganjam, Gajapati, Dhenkanal are the major lime growing areas in Odisha. The area and production of lime and lemon is 26.63 thousand ha and 261.07 thousand tonnes 
respectively in Odisha (Ministry of Agriculture, Horticulture Statistics at a Glance 2015).

Numerous cultivars of acid lime are cultivated in India with diversity of flavour and taste. Kuliana lime is a local elite land race of Mayurbhanj district, Odisha, where it is extensively grown as the hot summer and cold winter climate of the area is highly suitable for its cultivation. It is popular in the state for its size and juice content.

Since the lime plant has a wide range of soil and climatic adaptation, it is necessary to improve this fruit crop through planned breeding. Before going for breeding work for crop improvement, one should have sound knowledge on the growth pattern of the Kuliana lime plant. Flowering represents a phase transition from vegetative to reproductive growth. This phenomenon is one of the most important events in the plant life cycle because it is the initial stage in the sequence of producing a new generation.

Generally, the timing and rate of vegetative and reproductive growths are regulated by autonomous or environmental factors. Shoot growth in acid lime occurs in well defined waves (growth flushes) though default flushes are also seen. Acid lime plant puts forth three to four flushes in phases: uncontrolled flushing results in perpetuation of diseases and pests (Devi et al., 2011). Hence it is essential to study the growth pattern of the fruit crop as this will provides the useful information regarding the period of active carbohydrate synthesis, vigorous growth, dormancy period etc.

\section{Materials and Methods}

A field experiment was conducted on 4 year old air layered acid lime cultivar Kuliana lime planted at a spacing of $4 \times 4 \mathrm{~m}$ in Horticultural
Research Station, Department of Fruit Science and Horticulture Technology, O.U.A.T., Bhubaneswar during 2016-17. The research station is located at latitude of $20^{\circ} 15^{\prime} \mathrm{N}$ and longitude of $85^{\circ} 52^{\prime} \mathrm{E}$ which is about $60 \mathrm{~km}$ away from the Bay of Bengal having an altitude of $25.5 \mathrm{~m}$ above MSL, comes under the eighteenth agro climatic region of the country i.e. "Eastern Coastal Plain" and is termed as sub humid. The climate here is warm, humid with distinct summer, rainy and winter seasons.

The present experiment was conducted in "Random Effect Model under PROC MIXED through Statistical Analysis System (SAS) software" with three treatment (rainy season, winter season and spring season) and ten replication (plant 1 to plant 10). The duration of rainy season was from May-2016 to September-2016, the winter season from October-2016 to December-2016 and that of the spring season was from January-2016 to March-2017 in Bhubaneswar condition.

Ten uniform Kuliana lime plant were selected. Season and duration of new vegetative flush were recorded. The flush was observed from May 2016 to May 2017 and the different period of flush growth i.e. was distinctly noted. The various intercultural operations like irrigation, manuring, weeding etc. are done according to the recommendation for acid lime plant. Plant protection measures were taken as and when required to control the seasonal pests and diseases.

The height and girth of a plant in centimeter and millimeter respectively was measured in the beginning and cessation of each season. The plant height and girth at the end of the three seasons was recorded and the relative growth of the plant in height $(\mathrm{cm})$ and girth $(\mathrm{mm})$ on the three seasons was calculated. Canopy spread of each tree in North-South and East-West was measured in meter using 
measuring tape in $\mathrm{cm}$. The relative growth of canopy of the plant on the three seasons was recorded. Canopy volume in $\mathrm{m}^{3}$ was calculated by the following formula given by Roose et al., (1986) and the relative growth in canopy volume was determined in the particular season and expressed in $\left(\mathrm{cm}^{3}\right)$.

Canopy volume $=\frac{4 \times \pi \times \mathrm{h} \times \mathrm{r}^{2}}{6}\left(\mathrm{~cm}^{3}\right)$

Where, $\pi=2.14, \mathrm{~h}=$ Plant height $(\mathrm{cm})$ and $\mathrm{b}=$ $\frac{(\mathrm{N}-\mathrm{S})+(\mathrm{E}-\mathrm{W}) \text { canopy spread }}{4}(\mathrm{~cm})$

Branches emerging from secondary branches were called tertiary branches. Three representative secondary branches from upper, middle and lower portion of the plant on each direction were selected. The number of newly emerged shoot was recorded from those shoot and converted for the plant. The length, diameter and internode length of the shoot of the particular flush was measured in meter tape after two month from the emergence and expressed in centimetre, millimeter and centimeter respectively. The weight of 10 two month old sample shoot per replication was taken and the Fresh weight and dry weight of shoot were determined by the method suggested by Dubey and Yadav (2004). The leaves and spines in each newly emerged shoot after they attain full growth were counted and recorded.

\section{Results and Discussion}

The vegetative parameters like plant height, girth, canopy spread, new shoot, number of leaves and shoot weight are the indicator of final yield and these are recorded

\section{Plant height}

Among the three seasons rainy season recorded maximum $(35.76 \mathrm{~cm})$ growth in average plant height followed by spring season $(20.61 \mathrm{~cm})$. The minimum $(10.9 \mathrm{~cm})$ mean growth in plant height was noticed in the winter season (Table 1).

Among the differences of Least Squares Mean of the seasons rainy season shows the statistically superior increase $(24.86 \mathrm{~cm})$ in average plant height over the winter season $(\mathrm{P}<0.0001)$ followed by $15.15 \mathrm{~cm}$ in the rainy season over the spring season $(\mathrm{P}=0.0036)$ and the spring season recoded the minimum increase in average plant height of $9.70 \mathrm{~cm}$ over the winter season $(\mathrm{P}=0.0460)$.

Higher plant height in the rainy season may be attributed to the favourable climatic condition with higher relative humidity which helps in reducing the evapotranspirational loss of the plant and thereby more of the photosynthates for the vegetative growth. The findings are in line with (Cooper et al., 1963) and Deshmukh et al., (2015).

\section{Plant girth}

Rainy season recorded the maximum (13.41 $\mathrm{mm}$ ) average growth in plant girth followed by spring season $(9.97 \mathrm{~mm})$. The minimum $(3.81 \mathrm{~mm})$ was obtained in the winter season (Table 1). However from the differences of Least Squares Mean it was noticed that rainy season has significant Influence on increasing the plant girth of $9.60 \mathrm{~mm}$ over the winter season $(\mathrm{P}=0.0001)$. The increase of plant girth of $6.16 \mathrm{~mm}$ has been observed in spring season over the winter season $(\mathrm{P}=0.0053)$ and there is no significant difference for the same character in rainy season over the winter season which was in line with the findings of Dalal et al., (2013).

\section{Canopy spread (East-West)}

The canopy spread both in E-W and N-S direction is the reflection of fruiting area to the 
plant and varies significantly among the seasons. In spring season maximum (21.61 $\mathrm{cm})$ average canopy spread was recorded which was at par with the rainy season (19.00 $\mathrm{cm})$ and the lowest $(9.07 \mathrm{~cm})$ average canopy spread was obtained in the winter season (Table 1). Spring season over the winter season has significant Influence $(\mathrm{P}=0.0039)$ in increasing $(12.54 \mathrm{~cm})$ the average canopy spread of the plant in East- West direction followed by rainy season $(9.93 \mathrm{~cm})$ over winter season $(\mathrm{P}=0.0173)$. Rainy season and spring season are similar in this aspect and similar findings were recorded by Sing and Samaddar (1965), Soni and Randhawa (1975), Hittalmani et al., (1977) and Deshmukh et al., (2015).

\section{Canopy spread (North-South)}

In spring season maximum $(18.37 \mathrm{~cm})$ average canopy spread was recorded which was at par with the rainy season $(16.34 \mathrm{~cm})$ and the lowest $(9.28 \mathrm{~cm})$ was obtained in the winter season Between the seasons there was no significant difference in increasing the canopy spread of the plant in N-S direction (Table 1). Sing and Samaddar (1965); Soni and Randhawa (1975); Hittalmani et al., (1977) and Deshmukh et al., (2015) reported the similar findings.

\section{Canopy volume}

The rainy season recorded the maximum $\left(4403.81 \mathrm{~cm}^{3}\right)$ growth in plant canopy volume which is statistically at par with that of the spring season $\left(4310.63 \mathrm{~cm}^{3}\right)$ and the minimum $\left(556.35 \mathrm{~cm}^{3}\right)$ growth was observed in the winter season in Kuliana lime plant. Data presented on the differences of Least Squares Mean of the season clearly shows that there was significant increase of $3847.6 \mathrm{~cm}^{3}$ and $3754.28 \mathrm{~cm}^{3}$ in the canopy volume of the plant in the rainy season $(\mathrm{P}=0.006)$ and spring season $(\mathrm{P}=0.0071)$ over the winter season respectively. Spring season and rainy season are at par in increasing the canopy volume of Kuliana lime (Table 1). Similar findings have been recorded by Cull (1991); Deshmukh et al., (2015).

\section{New growth flush or tertiary shoots}

The spring season produced the highest (153.80) average number of tertiaries which is statistically superior to that of the rainy season (125.40) and the winter season produced lowest (93.57) average number of tertiaries (Table 2).

Data presented for the differences of Least Squares Mean of season on Table 3 shows that there was significant increase in the average production of tertiary of 60.23 in the spring season in the Kuliana lime plant over the winter season $(\mathrm{P}<0.0001)$ followed by 31.83 numbers in the rainy season over the winter season $(\mathrm{P}=0.0158)$ and an average increase of 28.40 numbers has been noticed in the spring season over the rainy season $(\mathrm{P}=0.0287)$. The findings are in line with Sing and Samaddar (1965); Soni and Randhawa (1975); Hittalmani et al., (1977) and Vand and Abdullah (2012).

\section{Number of leaves per shoot}

Rainy season recorded the maximum (14.23) number of leaves per shoot which is at par with that of the spring season (13.73). Winter season have the minimum (11.29) number of leaves per shoot. Both the rainy season and the winter season were significantly superior in production of leaves per shoot. There was no significant Influence of rainy season over the spring season on increasing the number of leaves per shoot but winter season shows a reduction of 2.94 number of leaves per shoot and 2.44 numbers of leaves per shoot in rainy season $(\mathrm{P}=0.0033)$ and spring season $(\mathrm{P}=0.0117)$ respectively (Table 2$)$. 
Table.1 Influence of season on plant height, girth, canopy spread and volume of Kuliana lime

\begin{tabular}{|c|c|c|c|c|c|c|}
\hline Season & Plant & $\begin{array}{l}\text { Relative } \\
\text { growth of } \\
\text { plant height } \\
\text { (cm) }\end{array}$ & $\begin{array}{l}\text { Relative } \\
\text { growth of plant } \\
\text { girth }(\mathbf{m m})\end{array}$ & $\begin{array}{l}\text { Relative } \\
\text { growth in } \\
\text { canopy }(\mathrm{E}- \\
\text { W) }(\mathrm{cm})\end{array}$ & $\begin{array}{c}\text { Relative } \\
\text { growth in } \\
\text { canopy }(\mathrm{N}- \\
\text { S) }(\mathrm{cm})\end{array}$ & $\begin{array}{c}\text { Relative } \\
\text { growth of } \\
\text { canopy volume } \\
\left(\mathrm{cm}^{3}\right)\end{array}$ \\
\hline \multirow[t]{11}{*}{ Rainy } & 1 & 29.46 & 7.6 & 18.46 & 8.2 & 1867.05 \\
\hline & 2 & 30.72 & 5.29 & 22.37 & 9 & 2695.58 \\
\hline & 3 & 42.8 & 24.5 & 16.2 & 12.4 & 3121.61 \\
\hline & 4 & 44.3 & 22.36 & 37.2 & 4.7 & 6934.8 \\
\hline & 5 & 28.9 & 11.9 & 8.6 & 29.65 & 3770.18 \\
\hline & 6 & 47.6 & 18.32 & 10.5 & 18.9 & 3668.63 \\
\hline & 7 & 29.4 & 14.67 & 39.45 & 32 & 13383.03 \\
\hline & 8 & 46.2 & 13 & 9.46 & 24.3 & 4695.15 \\
\hline & 9 & 27.5 & 6.8 & 11.4 & 8 & 992.86 \\
\hline & 10 & 30.7 & 9.7 & 16.37 & 16.23 & 2909.22 \\
\hline & Mean & 35.76 & 13.41 & 19.00 & 16.34 & 4403.81 \\
\hline \multirow{11}{*}{ Winter } & 1 & 6 & 1 & 5.1 & 4 & 44.3 \\
\hline & 2 & 2 & 4.5 & 8.09 & 6.2 & 36.42 \\
\hline & 3 & 1.8 & 5 & 7.9 & 3.96 & 22.58 \\
\hline & 4 & 12.5 & 3 & 9.3 & 4.4 & 209.19 \\
\hline & 5 & 7.8 & 2.6 & 7.5 & 3.9 & 90.39 \\
\hline & 6 & 10.5 & 2.3 & 7.1 & 5.5 & 148.64 \\
\hline & 7 & 12.3 & 6 & 13 & 15 & 859.85 \\
\hline & 8 & 14.6 & 4 & 25.5 & 22 & 2937.26 \\
\hline & 9 & 24.5 & 2.7 & 3.3 & 16.7 & 873.82 \\
\hline & 10 & 17 & 7 & 3.9 & 11.1 & 341.06 \\
\hline & Mean & 10.90 & 3.81 & 9.07 & 9.28 & 556.35 \\
\hline \multirow[t]{11}{*}{ Spring } & 1 & 3.35 & 6 & 12.5 & 6 & 102.23 \\
\hline & 2 & 28.2 & 5 & 26.3 & 24 & 6361.91 \\
\hline & 3 & 17.5 & 22.5 & 11.4 & 4.3 & 348.62 \\
\hline & 4 & 11.5 & 19 & 14.2 & 26 & 1657.05 \\
\hline & 5 & 1.5 & 11.7 & 14 & 2.8 & 37.75 \\
\hline & 6 & 13 & 8.3 & 35 & 8.36 & 2179.26 \\
\hline & 7 & 20.5 & 7 & 31 & 34 & 7722.77 \\
\hline & 8 & 36 & 6.7 & 33 & 22.4 & 9852 \\
\hline & 9 & 24 & 11.5 & 14.7 & 32.3 & 4727.26 \\
\hline & 10 & 50.5 & 2 & 24 & 23.4 & 10117.44 \\
\hline & Mean & 20.61 & 9.97 & 21.61 & 18.36 & 4310.63 \\
\hline SE (+) Season & & 3.3705 & 1.7094 & 2.8852 & 3.0318 & 998.55 \\
\hline $\begin{array}{l}\text { SE }(d)(+) \text { of } \\
\text { LSM }\end{array}$ & & 4.5273 & 1.9413 & 3.79 & 3.7298 & 1236.93 \\
\hline \multirow[t]{3}{*}{$\operatorname{Pr}>|t|$} & Rainy spring & 0.0036 & NS & NS & NS & NS \\
\hline & Rainy winter & $<0.0001$ & 0.0001 & 0.0173 & NS & 0.006 \\
\hline & Spring winter & 0.046 & 0.0053 & 0.0039 & NS & 0.0071 \\
\hline
\end{tabular}


Table.2 Influence of season on production of number of tertiary shoot per plant, number of leaves per shoot and number of spines per shoot in Kuliana lime

\begin{tabular}{|c|c|c|c|c|}
\hline Season & Plant & $\begin{array}{l}\text { Number of } \\
\text { tertiaries }\end{array}$ & $\begin{array}{c}\text { No of leaves per } \\
\text { shoot }\end{array}$ & $\begin{array}{c}\text { No of spines per } \\
\text { shoot }\end{array}$ \\
\hline \multirow[t]{11}{*}{ Rainy } & 1 & 130 & 15 & 15.4 \\
\hline & 2 & 167 & 12.82 & 15.25 \\
\hline & 3 & 127 & 13.29 & 13.2 \\
\hline & 4 & 144 & 12.8 & 15.3 \\
\hline & 5 & 127 & 13.2 & 13.4 \\
\hline & 6 & 108 & 17 & 17.4 \\
\hline & 7 & 164 & 13 & 13.2 \\
\hline & 8 & 96 & 14.2 & 14.2 \\
\hline & 9 & 100 & 14.83 & 15.2 \\
\hline & 10 & 91 & 16.2 & 16.6 \\
\hline & Mean & 125.40 & 14.23 & 14.92 \\
\hline \multirow[t]{11}{*}{ Winter } & 1 & 120 & 11.44 & 11.44 \\
\hline & 2 & 76 & 8.86 & 8.92 \\
\hline & 3 & 33.35 & 15.18 & 15.26 \\
\hline & 4 & 104 & 13.26 & 13.26 \\
\hline & 5 & 70 & 13.89 & 13.95 \\
\hline & 6 & 80.67 & 8.51 & 8.51 \\
\hline & 7 & 156 & 11.33 & 11.45 \\
\hline & 8 & 104 & 11.77 & 11.89 \\
\hline & 9 & 111 & 9.44 & 9.44 \\
\hline & 10 & 80.67 & 9.24 & 9.62 \\
\hline & Mean & 93.57 & 11.29 & 11.37 \\
\hline \multirow[t]{11}{*}{ Spring } & 1 & 210 & 12 & 12 \\
\hline & 2 & 171 & 16.33 & 16.33 \\
\hline & 3 & 86.66 & 17.67 & 18 \\
\hline & 4 & 156 & 14.33 & 14.67 \\
\hline & 5 & 180 & 13.34 & 14.34 \\
\hline & 6 & 176 & 13 & 13 \\
\hline & 7 & 174 & 13.33 & 14.33 \\
\hline & 8 & 130.66 & 13.67 & 13.67 \\
\hline & 9 & 168.7 & 12.67 & 13.33 \\
\hline & 10 & 85 & 11 & 11.33 \\
\hline & Mean & 153.80 & 13.73 & 14.10 \\
\hline SE ( \pm ) Season & & 10.8139 & 0.6157 & 0.6073 \\
\hline $\operatorname{SE}(d)( \pm)$ of LSM & & 11.948 & 0.8707 & 0.8589 \\
\hline \multirow{3}{*}{$\operatorname{Pr}>|t|$} & Rainy spring & 0.0287 & NS & NS \\
\hline & Rainy winter & 0.0158 & 0.0033 & 0.0006 \\
\hline & Spring winter & $<0.0001$ & 0.0117 & 0.0053 \\
\hline
\end{tabular}


Table.3 Influence of season on shoot length, shoot diameter, internode length, fresh weight of shoot and dry weight of the shoot of Kuliana lime

\begin{tabular}{|c|c|c|c|c|c|c|}
\hline Season & Plant & $\begin{array}{c}\text { Shoot } \\
\text { length } \\
\text { (cm) }\end{array}$ & $\begin{array}{c}\text { Shoot } \\
\text { diameter } \\
(\mathrm{mm})\end{array}$ & $\begin{array}{l}\text { Inter-node } \\
\text { length }(\mathrm{cm})\end{array}$ & $\begin{array}{c}\text { Fresh } \\
\text { weight of } \\
\operatorname{shoot}(\mathrm{g})\end{array}$ & $\begin{array}{c}\text { Dry } \\
\text { weight of } \\
\operatorname{shoot}(g)\end{array}$ \\
\hline \multirow[t]{11}{*}{ Rainy } & 1 & 19.3 & 3.5 & 1.46 & 5.75 & 2.17 \\
\hline & 2 & 14.95 & 3.9 & 1.38 & 4.96 & 2.09 \\
\hline & 3 & 17.58 & 4.6 & 1.39 & 6.92 & 2.18 \\
\hline & 4 & 16.5 & 4.1 & 1.46 & 4.98 & 2.13 \\
\hline & 5 & 16.4 & 2.9 & 1.32 & 4.05 & 1.98 \\
\hline & 6 & 19.1 & 4.8 & 1.4 & 5.95 & 2.48 \\
\hline & 7 & 17.36 & 4.6 & 1.34 & 4.02 & 1.95 \\
\hline & 8 & 14.8 & 4.1 & 1.35 & 4.18 & 1.96 \\
\hline & 9 & 15.93 & 3.7 & 1.32 & 4.56 & 1.86 \\
\hline & 10 & 15.86 & 4.2 & 1.3 & 6.93 & 2.32 \\
\hline & Mean & 16.78 & 4.04 & 1.37 & 5.23 & 2.11 \\
\hline \multirow[t]{11}{*}{ Winter } & 1 & 12.47 & 2.7 & 1.09 & 3.19 & 1.5 \\
\hline & 2 & 9.93 & 2.4 & 1.12 & 4.12 & 1.13 \\
\hline & 3 & 16.25 & 3.6 & 1.07 & 4.05 & 1.22 \\
\hline & 4 & 15.25 & 3.3 & 1.15 & 3.29 & 1.34 \\
\hline & 5 & 13.62 & 2.1 & 0.98 & 3.55 & 1.37 \\
\hline & 6 & 9.45 & 2.2 & 1.11 & 4.12 & 1.12 \\
\hline & 7 & 12.8 & 3.4 & 1.13 & 3.48 & 1.13 \\
\hline & 8 & 12.96 & 2.8 & 1.16 & 3.96 & 1.09 \\
\hline & 9 & 10.2 & 2.7 & 1.08 & 4.15 & 1.39 \\
\hline & 10 & 10.16 & 2.3 & 1.1 & 4.12 & 1.34 \\
\hline & Mean & 12.31 & 2.75 & 1.10 & 3.80 & 1.26 \\
\hline \multirow[t]{11}{*}{ Spring } & 1 & 14.6 & 3.2 & 1.17 & 4.27 & 1.8 \\
\hline & 2 & 14.37 & 2.9 & 1.26 & 4.57 & 1.6 \\
\hline & 3 & 19.23 & 4.5 & 1.33 & 4.6 & 2.1 \\
\hline & 4 & 17.33 & 4.3 & 1.33 & 4.26 & 2 \\
\hline & 5 & 15.6 & 2.4 & 1.27 & 4.33 & 1.57 \\
\hline & 6 & 12.83 & 2.5 & 1.13 & 3.5 & 1.13 \\
\hline & 7 & 16.6 & 3.6 & 1.38 & 3.8 & 1.77 \\
\hline & 8 & 15.87 & 3.4 & 1.26 & 4.13 & 1.87 \\
\hline & 9 & 13.47 & 2.9 & 1.26 & 4.46 & 1.2 \\
\hline & 10 & 13.3 & 2.6 & 1.16 & 4.27 & 1.1 \\
\hline & Mean & 15.32 & 3.23 & 1.25 & 4.22 & 1.61 \\
\hline SE (土) Season & & 0.6317 & 0.1947 & 0.02028 & 0.2231 & 0.07894 \\
\hline $\begin{array}{c}\text { SE(d) }( \pm) \text { of } \\
\text { LSM }\end{array}$ & & 0.6946 & 0.1780 & 0.0273 & 0.2941 & 0.1116 \\
\hline \multirow[t]{3}{*}{$\operatorname{Pr}>|t|$} & Rainy Spring & NS & 0.0002 & 0.0004 & 0.0029 & 0.0003 \\
\hline & Rainy Winter & $<0.0001$ & $<0.0001$ & $<0.0001$ & 0.0001 & $<0.0001$ \\
\hline & Spring Winter & 0.0004 & 0.0148 & $<0.0001$ & NS & 0.0056 \\
\hline
\end{tabular}


Sema and Sanyal (2002) also reported that there is no significant difference in the number of leaves per shoot as influenced by the different seasons or growth flushes (Debbarma and Hazarika, 2016).

\section{Number of spines per shoot}

The maximum numbers of spines per shoot are recorded by the rainy season flush (14.92) followed by the spring season flush (14.10) and the lowest were in the winter season flush (11.37).

The difference of Least Squares Mean shows that there was no significant difference among the rainy season and winter season, however both rainy season $(\mathrm{P}=0.0006)$ and spring season $(\mathrm{P}=0.0053)$ were recorded to be superior to the winter season by 3.54 and 2.73 numbers of spines per shoot (Table 2) (Debbarma and Hazarika, 2016).

\section{Length of the shoot}

Maximum shoot length was observed in the rainy season flush $(16.78 \mathrm{~cm})$ which is statistically at par with that of the spring season flush $(15.32 \mathrm{~cm})$. The winter season flush recorded the minimum length of the shoot $(12.31 \mathrm{~cm})$.

The result of differences of Least Squares Mean of the season clearly indicated that there was $4.47 \mathrm{~cm}$ and $3.01 \mathrm{~cm}$ increase in the length of the shoot in Kuliana lime in rainy season ( $\mathrm{P}<0.0001)$ and spring season $(\mathrm{P}=0.0004)$ over the winter season and there is no significant Influence of rainy season over the spring season (Table 3). Similar result has also been reported by Singh et al., (1985). Sema and Sanyal (2002) reported that winter flush have higher rate of growth (length and diameter) but the cumulative length of shoot was higher in rainy season flush in lemon trees.

\section{Diameter of the shoot}

In rainy season maximum $(4.04 \mathrm{~mm})$ average shoot diameter was observed followed by the spring season $(3.23 \mathrm{~mm})$ and the minimum $(2.75 \mathrm{~mm})$ was in the winter season (Table 3$)$. An increase of $1.29 \mathrm{~mm}$ and $0.81 \mathrm{~mm}$ has been observed in the average diameter of the shoot in rainy season over the winter season $(\mathrm{P}<0.0001)$ and the spring season $(\mathrm{P}=0.0002)$ respectively. The spring season recorded an increase of average shoot diameter of 0.48 $\mathrm{mm}$ over the spring season $(\mathrm{P}=0.0148)$ which was in line with the findings of Singh et al., (1985) and Sema and Sanyal (2002).

\section{Inter-node length}

Maximum average inter-node length was obtained in the rainy season flush $(1.37 \mathrm{~cm})$ followed by the spring season flush $(1.25 \mathrm{~cm})$ and the minimum in winter season flush $(1.10$ $\mathrm{cm})$. All the three seasons have significant Influence on increasing the inter-node length of the shoot (Table 3). An average increase in inter node length of shoot of $0.27 \mathrm{~cm}$ was noticed in the rainy season over the winter season $(\mathrm{P}=0.0004)$ followed by $0.16 \mathrm{~cm}$ in the spring season over the winter season $(\mathrm{P}<0001)$ and the lowest was $0.12 \mathrm{~cm}$ in the rainy season over the spring season $(\mathrm{P}<0.0001)$.

\section{Fresh weight of the shoot}

Maximum (5.23 g) fresh weight of the shoot was observed in the rainy season flush which was statistically at par with that of the spring season flush $(4.22 \mathrm{~g})$ and the minimum $(3.80 \mathrm{~g})$ fresh weight of the shoot was obtained in the winter season growth flush (Table 3). Rainy season and spring season have significant Influence on increasing the fresh weight of the season. An average increase $1.43 \mathrm{~g}$ and $1.01 \mathrm{~g}$ in fresh weight of the shoot has been observed in rainy season 
over the winter season $(\mathrm{P}=0.0001)$ and spring season $(\mathrm{P}=0.0029)$ respectively. The impact of spring season in increasing fruit length is at par with the winter season. The leaves of rainy season flush showed the maximum leaf area and leaf fresh weight which may be due to the better availability of soil moisture and high relative humidity resulting in low transpirational losses which favours the better leaf growth in terms of area and fresh weight. The minimum leaf area of the spring season may be due to higher summer temperature at sampling time in April resulted in rapid transpirational loss and the spring season growth must serve as a sink for the developing fruits. The present findings are in conformity with the findings of Dalal et al., (2013) in Kinnow mandarin.

\section{Dry weight of the shoot}

Rainy season recorded the highest $(2.11 \mathrm{~g})$ dry weight of the shoot of the new growth flush followed by the spring season (1.61 g). The lowest $(1.26 \mathrm{~g})$ dry weight of shoot was recorded in winter season growth flush (Table 3). All the three seasons have significant contribution for the dry weight of the shoot. An average increase of $0.85 \mathrm{~g}, 0.50 \mathrm{~g}$ and $0.35 \mathrm{~g}$ were observed in the dry weight of the shoot in rainy season over winter season $(\mathrm{P}<0.0001)$, rainy season over spring season $(\mathrm{P}=0.0003)$ and spring season over winter season $(\mathrm{P}=0.0056)$ respectively. The low dry weight of spring flush leaves as compared to rainy flush indicated that reserve carbohydrate were utilized to sustain the early stage of reproductive development. The rainy season flush leaves were having higher leaf dry weight it might be due to less catabolic (respiration) loss of the plant due to favourable climatic condition which increases the storage of more solutes in plant leaves. Similar results were also observed by Shimizu et al., (1978) and Akao et al., (1981) who reported the reserved carbohydrate in spring flush leaves were utilized mainly to support reproductive growth while old leaves photosynthesis supplied the need of vegetative growth.

From our study, it can be concluded that the contribution of rainy season on the different vegetative growth parameters are immense. Maximum photosynthates might be diverted to the emerging shoot which helps in their proper growth. Plant growth has been noticed to be retarded during winter season. The production of tertiary shoot was more during the spring season.

\section{Acknowledgements}

The authors are thankful to the Dilip Kumar Dash, Professor and Head, Department of Fruit Science and Horticulture Technology, OUAT, for providing the required research facilities.

\section{References}

Akao, S., Tsukahara, S., Hisada, H. and Ono, S. 1981. Contribution of photosynthetic assimilates to development of flower and spring flush in Citrus unshiu Marc, Journal of Japanese Society of Horticultural Science, 50: 1-9.

Cooper, W.C., Peynad, A., Furr, J.R., Hilgemanu, R.H., Cahoon, G.A. and Boswell, S.B. 1963. Tree growth and fruit quality of valencia oranges in relation to climate, American Society for Horticultural Science, 82: 180-192.

Cull, B.W. 1991. Mango crop management, Acta Horticulturae, 291: 154-173.

Dalal, R.P.S., Beniwal, B.S. and Sehrawat, S.K. 2013. Seasonal Variation in Growth, Leaf Physiology and Fruit Development in Kinnow, a Mandarin Hybrid, Journal of Plant Studies, 2(1): 72-77. 
Debbarma, N. and Hazarika, B.N. 2016. Effect of plant growth regulators and chemicals on yield and quality of acid lime (Citrus aurantifolia Swingle) under foothill condition of Arunachal Pradesh, International Journal of Agriculture, Environment and Biotechnology, 9(2): 231-236.

Deshmukh, G.N., Alekar, A.N. and Hirve, P.S. 2015. Performance of acid lime varieties for hasta bahar under Akola conditions, Journal of Horticulture, 2(2): 131.

Devi, H.L., Sarkar, S.K., Dhanabati, L. and Majhi, D. 2011. Flushing - flowering behavior and regulation in acid lime-A critical review and research interventions, Journal of Crop and Weed, 7(2):87-90.

Dubey, A.K. and Yadav, D.S. 2004. Studies on growth pattern of citrus species during spring flush, Indian Journal of Agriculture Research, 38(1): 50-54.

Hittalmani, S.V. 1977. Studies on growth and fruiting in kagzi (Citrus aurantifolia Swingle) and Tahiti (Citrus latifolia Tanaka) limes, Mysore Journal of Agricultural Sciences, 11: 113.

Ministry of Agriculture and Farmer Welfare, Govt. of India, 2015, Horticulture statistics at a glance, Oxford publication: 181 .

NHB. 2014. NHB database, National Horticulture Board, Gurgoan, Haryana122015: 44-45.

Roose, M.L., Coel, D.A., Atkin, D. and Kuper, R.S. 1986. Yield and tree size of four citrus cultivars on 21 rootstocks in
California, Journal of the American Society for Horticulture Science, 3(2): 123-126.

Sema, A. and Sanyal, D. 2002. Dynamics of shoot growth and chlorophyll content in lemon as influenced by flush age and type of shoot, Indian Journal of Horticulture, 59(2): 130-134.

Shimizu, T., Torikara, H. and Torii, S. 1978. Studiers on the effect of crop load on the composition of Satsuma mandarin trees. V. Analysis of production processes of bearing and non-bearing trees based on the carbohydrate economy. Journal of the Japanese Society of Horticulture Science, 46: 465-478.

Singh, J.P. and Samaddar, H.M. 1965. Fruiting in relation to growth in sweet lime, Indian Journal of Horticulture, 22:131-140.

Singh, P.N., Singh, R.P. and Singh, R. 1985. Seasonal changes in vegetative growth of two cultivars of lemon (Citrus limon Burm) in relation to weather parameters and soil temperature. Haryana Journal of Horticultural Sciences, 14: 37-40.

Soni, S.L. and Randhawa. 1975. Relation of growth and fruiting in lemon (Citrus limon Burm.), Indian Jounal of Horticulture, 32: 35-44.

Vand, S.H. and Abdullah, T.L. 2012. Identification and Introduction of Thornless Lime (Citrus aurantifolia) in Hormozgan, Iran, Indian Journal of Science and Technology, 5(11): 36703673.

\section{How to cite this article:}

Subhrajyoti Mishra, Kommana Pavani, Priyadarshini Dalei and Dilip Kumar Dash. 2018. Effect of Season on Growth Dynamics of Citrus aurantifolia cv. Kuliana Lime under Bhubaneswar Condition. Int.J.Curr.Microbiol.App.Sci. 7(02): 2911-2920. doi: https://doi.org/10.20546/ijcmas.2018.702.353 